\title{
FATTY ACIDS COMPOSITION AND TRANS ISOMERS IN CHEESES AND CHEESE-LIKE PRODUCTS
}

\author{
SKŁAD KWASÓW TŁUSZCZOWYCH ORAZ IZOMERÓW TRANS \\ W SERACH ORAZ WYROBACH SEROPODOBNYCH
}

\begin{abstract}
Summary
Background. Cheeses are a very important component of our diet. The assortment of cheeses on the Polish market is very large. Besides commercial cheeses, cheeses from individual farms are available, as well as cheese-like products, which are more likely to be bought by consumers for their lower prices. The aim of the study was to evaluate the fatty acid composition, with particular focus on cis9trans $11 \mathrm{C} 18: 2$ (CLA), trans isomers of C18:1 and C18:2 fatty acid content, in commercial cheeses, cheeses made by farmers, and cheese-like products.

Material and methods. The study evaluated commercial rennet ripening cheese from different manufacturers ( 8 products), cheese-like products from different manufacturers ( 8 products) and ranching rennet ripening cheese derived from individual producers ( 8 products). Determination of the fatty acid composition was performed by GC-FIDupe in $100 \mathrm{~m}$ capillary column with CP Sil 88 phase. Reference milk fat and fatty acid methyl esters standards from Sigma and Supelco were used for identification of fatty acids.

Results. The study showed that the tested commercial cheese, cheese made by farmers and cheese-like products were characterized by varying fat content, as well as a diverse composition of individual groups of fatty acids. Within a single group of products the biggest difference in the content of individual groups of fatty acids was observed in the cheese made by farmers.

Conclusions. Based on extensive studies it can be concluded that the commercial cheese and cheese made by farmers are characterized by a higher content of saturated and short-chain fatty acids than in cheese-like products and a lower content of monoenoic and polyenoic acids than in cheese-like products. Cheeses are a better source of conjugated linoleic acid in our diet than are cheese-like products.
\end{abstract}

Key words: fatty acids, CLA, trans isomers, cheeses, cheese-like products 
Paszczyk, B., Polak-Śliwińska, M., Łuczyńska, J. (2016). Fatty acids composition and trans isomers in cheeses and cheese-like products. Nauka Przyr. Technol., 10, 4, \#45. DOI: http://dx.doi.org/10.17306/J.NPT.2016.4.45

\section{Introduction}

Milk fat is rated among the most complex edible fats in respect of fatty acids composition. Over 400 fatty acids have been found in its composition. Fatty acids present in the fat are those containing 2-28 carbon atoms, having both even and odd number of carbon atoms, acids of various saturation degree (saturated, monoenoic and polyenoic), acids of cis or trans configuration (Jensen, 2002; Przybojewska and Rafalski, 2004; Żebrowska et al., 2009; Żelazna and Popielarska, 2003).

A characteristic feature of milk fat is the presence of a high content of saturated, as well as short-chain fatty acids (C4 do $\mathrm{C} 10)$ which constitute approx. $10 \%$ of the total composition of the acids. As it is reported by Lipiński et al. (2012), the proportion of saturated fatty acids in milk fat oscillates from $61.75 \%$ to $73.14 \%$. The remaining part are monoenoic (from $21.53 \%$ to $30.93 \%$ ) and polyenoic acids (from $2.36 \%$ to $5.04 \%$ ). The quantitative content of individual fatty acids constituting the milk fat composition changes influenced by various factors such as: feeding, breed, lactation time, age and others (Barłowska and Litwińczuk, 2009; Frelich et al., 2012; Kuczyńska et al., 2011; Lipiński et al., 2012; Radkowska, 2013; Sobotka et al., 2015). The type of the applied feeding influences, to the highest degree (among the above-mentioned factors), the profile of fatty acids in milk fat. Milk fat in the season of green fodder cows' feeding contains significantly more $\mathrm{C} 18$ group acids, mainly $\mathrm{C} 18: 1$, and significantly less palmitic and myristic acids than in the cowshed feeding season. Milk fat from the pasture cow feeding season shows a higher content of conjugated linoleic acid cis9trans11 C18:2 (CLA), and trans isomers of C18:1 and C18:2 acids (Capuano et al., 2015; Lipiński et al., 2012; Żegarska et al., 2006). Milk fat is the richest and the most natural source of CLA in our diet, and contains, on average, $4.5 \mathrm{mg}$ CLA in $1 \mathrm{~g}$ of fat (Barłowska et al., 2016a). The acid performs a sequence of health-promoting characteristics e.g.: counterneoplastic, counterdiabetic and immunomodulatory (Przybojewska and Rafalski, 2003a).

According to Żegarska et al. (2006) the proportion of cis 9 trans $11 \mathrm{C} 18: 2$ acid in fat from the winter period oscillated in the range between $0.32 \%$ to $0.52 \%$ of the total fatty acids composition, whereas from the summer period from $1.06 \%$ to $1.76 \%$. Specific conditions in individual farms, e.g. varied feed, may have an impact on milk quality, as well as the level of fatty acids in the milk (Barłowska et al., 2016b; Rembiałkowska and Załęcka, 2012). The research of Popović-Vranjeś et al. (2011) proved that ecological milk showed a lower content of both saturated and monoenoic fatty acids, and a higher content of polyenoic fatty acids compared to milk from conventional farms' cows (Barłowska et al., 2016b; Rembiałkowska and Załęcka, 2012). The research conducted by Popović-Vranjeś et al. (2011) reported that the content in ecological milk, depending on the feeding system, oscillated from $0.381 \%$ to $0.946 \%$ in winter milk and from $0.931 \%$ to $2.046 \%$ in milk from the summer feeding period. Cheeses are a significant component of our diet. The assortment of cheeses on the Polish market is very wide. More and more frequently, besides commercial cheeses, you can buy cheeses from individual farms, where varied animals feeding is practised. The cheeses are becoming more and more popular with consumers today. Parallel, the Polish market also offers a variety of cheese-like products which are made with a participation, or total substitution, of milk fat by cheaper plant fats (Aljewicz et al., 2011). As far as the chemical 
Paszczyk, B., Polak-Śliwińska, M., Łuczyńska, J. (2016). Fatty acids composition and trans isomers in cheeses and cheese-like products. Nauka Przyr. Technol., 10, 4, \#45. DOI: http://dx.doi.org/10.17306/J.NPT.2016.4.45

composition is concerned, cheese-like products are not meaningfully different from the original ripening cheeses. Yet, their biological value is different owing to the fact of substituting the milk fat with plant fat (Aljewicz et al., 2010). Cheese-like products, due to their lower price compared to cheeses, are frequently purchased by consumers and that is why their quality control is crucial. The aim of the study was to evaluate the fatty acid composition, with particular focus on cis9trans11 C18:2 (CLA), trans isomers of C18:1 and C18:2 fatty acids content in commercial cheeses, cheeses made by farmers and cheese-like products.

\section{Material and methods}

The study evaluated commercial rennet ripening cheeses from different manufacturers ( 8 products), cheese-like products from different manufacturers ( 8 products) and ranching rennet ripening cheese coming from individual producers ( 8 products). All the products were purchased in May, 2015. Commercial rennet ripening cheeses and cheese-like products were bought in shops in Olsztyn. The farm cheeses were purchased during the Festiwal of Farm and Traditional Cheeses. The content of fat in the researched cheeses, as well as cheese-like products, was determined by Schmidt-Bondzyński-Ratzlaff's (PN-73/A-86232, 1973) method. While to determine the composition of fatty acids, the fat from cheeses and cheese-like products was separated by Folch et al. (1957) method. Methyl esters of fatty acids were prepared from the separated fat according to IDF 182:2002 (ISO 15884:2002, 2002) method. The composition of fatty acids was determined applying the method of gas chromatography by help of Hewlett Packard 6890 GC System (Germany) with a flame ionization detector (FID), in 100 m capillary column (produced by Chrompack) with CP Sil 88 phase. The column diameter was $0.25 \mathrm{~mm}$, the film was $0.20 \mu \mathrm{m}$ thick. The determinations were carried out in the following conditions: column temperature from $60^{\circ} \mathrm{C}$ (for $1 \mathrm{~min}$ ) to $180^{\circ} \mathrm{C}, \Delta \mathrm{t}=$ $5^{\circ} \mathrm{C} / \mathrm{min}$, detector's temperature $250^{\circ} \mathrm{C}$, injector's temperature $225^{\circ} \mathrm{C}$, carrier gas helium, gas flow $1.5 \mathrm{~cm}^{3} / \mathrm{min}$. Identification of fatty acids was carried out based on the comparison of their retention time with the retention time of methyl esters of fatty acids of reference milk fat (BCR Reference Materials) of CRM 164 symbol. To identify cis9trans11 C18:2 (CLA) acid, a mixture of methyl esters cis9trans11-octadecadienoic and cis 10 trans 12 -octadecadienoic, produced by Sigma was used. To identify the isomers of cis9trans 11 -octadecadienoic and cis 10 trans 12 -octadecadienoic the standards were used: trans6-octadecen produced by Supelco, trans9-octadecen and trans 11 -octadecen produced by Sigma. Identification of trans acid C18:2 was carried out comparing the retention time and the mixture of standards of C18:2 acid isomers: trans 9 trans 12 -octadecadienoic, cis9trans 12 -octadecadienoic, trans 9 cis 12 -octadecadienoic, cis9cis 12-octadecadienoic produced by Supelco.

The percentage proportion of the assayed fatty acids was presented in mass percentage (as a percentage proportion of individual fatty acids in relation to general fatty acids composition). The conducted statistical analyses were carried out applying STATISTICA 10 program. Monofactorial analysis of variance (ANOVA) was applied at the significance level $p=0.05$. Duncan's test was used to define the differences between mean values. 
Paszczyk, B., Polak-Śliwińska, M., Łuczyńska, J. (2016). Fatty acids composition and trans isomers in cheeses and cheese-like products. Nauka Przyr. Technol., 10, 4, \#45. DOI: http://dx.doi.org/10.17306/J.NPT.2016.4.45

\section{Results and discussion}

The results presented in Table 1 indicate that the commercial cheeses were situated in the interval from $18.40 \%$ to $26.20 \%$ of fat content. Fat, in the rennet ripening cheeses examined by Rutkowska et al. (2009), ranged from $20.30 \%$ to $28.68 \%$. Full fat cheeses purchased in Finland, and examined by Ritvanen et al. (2012), contained fat in the interval from $23.8 \%$ to $30.1 \%$.

Table 1. Fat content in cheeses and cheese-like products, as well as share of some groups of fatty acids in their total (\%)

Tabela 1. Zawartość tłuszczu w serach i wyrobach seropodobnych oraz udział poszczególnych grup kwasów tłuszczowych w ich ogólnym składzie (\%)

\begin{tabular}{|c|c|c|c|c|c|c|c|c|c|}
\hline \multirow{2}{*}{$\begin{array}{l}\text { Fat and acids } \\
\text { Tłuszcz i kwasy }\end{array}$} & \multicolumn{3}{|c|}{$\begin{array}{l}\text { Commercial cheeses } \\
\text { Sery handlowe } \\
(\mathrm{n}=8)\end{array}$} & \multicolumn{3}{|c|}{$\begin{array}{l}\text { Cheese-like products } \\
\text { Wyroby seropodobne } \\
\qquad(\mathrm{n}=8)\end{array}$} & \multicolumn{3}{|c|}{$\begin{array}{c}\text { Cheeses made by farmers } \\
\text { Sery farmerskie } \\
(\mathrm{n}=8)\end{array}$} \\
\hline & Min & Max & $\bar{x} \pm \mathrm{SD}$ & Min & Max & $\bar{x} \pm \mathrm{SD}$ & Min & Max & $\bar{x} \pm \mathrm{SD}$ \\
\hline $\begin{array}{l}\text { Fat content } \\
\text { Zawartość tłuszczu }\end{array}$ & 18.40 & 26.20 & $\begin{array}{l}\mathbf{2 3 . 1 3}^{\mathbf{b}} \\
\pm 2.42\end{array}$ & 20.70 & 26.10 & $\begin{array}{c}\mathbf{2 3 . 7 5}^{\mathbf{b}} \pm \\
2.02\end{array}$ & 26.04 & 43.97 & $\begin{array}{l}\mathbf{3 5 . 4 4}^{\mathrm{a}} \\
\pm 6.54\end{array}$ \\
\hline $\begin{array}{l}\sum \text { of short-chain } \\
\text { fatty acids (C4-C10) } \\
\sum \text { kwasów krótko- } \\
\text { lańcuchowych } \\
\text { (C4-C10) }\end{array}$ & 8.75 & 10.32 & $\begin{array}{c}\mathbf{9 . 3 5}^{\mathbf{b}} \\
\pm 0.56\end{array}$ & 0.00 & 0.62 & $\begin{array}{c}\mathbf{0 . 2 0}^{\mathbf{c}} \\
\pm 0.21\end{array}$ & 9.83 & 12.51 & $\begin{array}{l}\mathbf{1 0 . 7 3}^{\mathrm{a}} \\
\pm 0.97\end{array}$ \\
\hline $\begin{array}{l}\sum \text { of saturated fatty } \\
\text { acids } \\
\sum \text { kwasów nasyco- } \\
\text { nych }\end{array}$ & 57.57 & 61.74 & $\begin{array}{l}\mathbf{5 9 . 0 3}^{\mathbf{b}} \\
\pm 1.29\end{array}$ & 49.40 & 52.84 & $\begin{array}{l}\mathbf{5 1 . 1 8}^{\mathbf{c}} \\
\pm 1.40\end{array}$ & 56.12 & 66.37 & $\begin{array}{l}\mathbf{6 2 . 0 7}^{\mathrm{a}} \\
\pm 3.54\end{array}$ \\
\hline $\begin{array}{l}\sum \text { of monoenoic } \\
\text { fatty acids } \\
\sum \text { kwasów mono- } \\
\text { enowych }\end{array}$ & 27.47 & 29.46 & $\begin{array}{l}\mathbf{2 8 . 2 1}^{\mathbf{b}} \\
\pm 1.18\end{array}$ & 37.41 & 41.35 & $\begin{array}{l}\mathbf{3 9 . 2 9}^{\mathrm{a}} \\
\pm 1.78\end{array}$ & 18.82 & 29.58 & 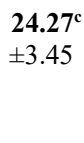 \\
\hline $\begin{array}{l}\sum \text { of polyenoic fatty } \\
\text { acids } \\
\sum \text { kwasów polieno- } \\
\text { wych }\end{array}$ & 2.74 & 3.91 & $\begin{array}{r}\mathbf{3 . 4 3}^{\mathbf{b}} \\
\pm 0.39\end{array}$ & 8.82 & 9.85 & $\begin{array}{r}\mathbf{9 . 2 3}^{\mathbf{a}} \\
\pm 0.37\end{array}$ & 2.40 & 4.10 & $\begin{array}{r}\mathbf{2 . 9 9}^{\mathbf{b}} \\
\pm 0.67\end{array}$ \\
\hline
\end{tabular}

$\mathrm{n}$ - number of samples, Min - minimum value, Max - maximum value, $\bar{x}-$ mean value, $\mathrm{SD}-$ standard deviation.

Mean values denoted in the rows by the same letter do not differ statistically significantly $(\mathrm{p} \leq 0.05)$.

$\mathrm{n}$ - liczba próbek, Min - wartość minimalna, Max - wartość maksymalna, $\bar{x}$ - wartość średnia, SD - odchylenie standardowe.

Wartości średnie oznaczone w wierszach tą samą literą nie różnią się statystycznie istotnie $(\mathrm{p} \leq 0,05)$.

Farmer cheeses showed a significantly higher mean fat content compared to commercial cheeses (Table 1). In the examined farmer cheeses, the content of fat was varied and oscillated from $26.04 \%$ to over $43 \%$. Such a meaningful differentiation of fat con- 
Paszczyk, B., Polak-Śliwińska, M., Łuczyńska, J. (2016). Fatty acids composition and trans isomers in cheeses and cheese-like products. Nauka Przyr. Technol., 10, 4, \#45. DOI: http://dx.doi.org/10.17306/J.NPT.2016.4.45

tent in the cheeses may result from a various milk quality used in the process of cheese production in individual farms. A higher fat content in some of the cheeses in focus may prove lack of normalization of fat content in the milk used in the production of the tested cheeses. A high variability of fat content (interval $21.72 \%$ to $45.17 \%$ ) was observed also in the case of the tested cheeses from ecological production (Paszczyk, 2015). The fat in cheese-like products, on which the studies were focused, was at similar levels (Table 1). Its content in cheese-like products, purchased in shops in Olsztyn in 2013, ranged from $20.70 \%$ to $27.50 \%$ (Paszczyk, 2014). Rape oil added cheeses bought in Finland, tested by Ritvanen et al. (2012), contained from $12.3 \%$ to $19.3 \%$ of fat. The fat separated from commercial and farmer cheeses and cheese-like products was characterized by a varied proportion of individual fatty acids groups: short-chain, saturated, monoenoic and polyenoic. Diversification was observed both between the groups of the investigated products, and also inside them. The highest diversification in the individual fatty acids' groups was found in farmer cheeses. Such a high diversification, especially of mono- and polyenoic fatty acids in the examined samples of farmer cheeses, may have been influenced by: quality of milk used for their production, and the conditions the production cycle was conducted in. It can be suspected that the cheeses characterized by a higher proportion of unsaturated acids, and lower of saturated ones, were produced from the milk coming from the summertime cows' feeding. According to the research by Rutkowska et al. (2009), and Zeppa et al. (2003), the cheeses from the summer season period show a higher unsaturated acids content, and lower of the saturated ones, compared to cheeses coming from the winter season. All the tested cheeses were purchased in May, and some samples may have come from the summer production and may have been ripening for a longer time than the other examined cheeses. The results in Table 1 indicate that saturated fatty acids were dominant in the fat of all the examined commercial and farmer cheeses, as well as cheese-like products. Talpur et al. (2008) examined Pakistani cheeses and found that saturated fatty acids reached $64.85 \%$. Similar contents of fatty acids were found by Prandini et al. (2011), as well as Ritvanen et al. (2012). The content of fatty acids in cheese-like products bought in Olsztyn in 2013 was in the range from $49.76 \%$ to $52.96 \%$ (Paszczyk, 2014). Rape oil added cheeses purchased in Finland and tested by Ritvanen et al. (2012) contained 7.51\% of saturated fatty acids. The lowest mean content of short-chain fatty acids was characteristic of cheese-like products. Significantly higher content of the acids was found in commercial and farmer cheeses (Table 1). The obtained results indicate that the cheese-like products showed a meaningfully higher content of monoenoic fatty acids (Table 1) than commercial and farmer cheeses. The cheese-like products purchased in Olsztyn contained from $37.61 \%$ to $41.19 \%$ monoenoic fatty acids, according to the research published in 2014 (Paszczyk, 2014). The rape oil added cheeses examined by Ritvanen et al. (2012) showed the presence of $64.4 \%$ of monoenoic acids. The content of this group of fatty acids in commercial cheeses from the winter period, examined by Grega et al. (2005), oscillated from $20.81 \%$ to $28.92 \%$ in total fatty acids composition.

The acids constituted from $24.93 \%$ to $30.21 \%$ in the summertime cheeses examined by the authors. Monoenoic acids occurred in the quantity ranging from $28.8 \%$ to $32.8 \%$ in the cheeses from the period May-October, 2007, examined by Rutkowska et al. (2009). The content of the acids in cheeses, from the period November, 2007 - August, 2008 , ranged from $22.8 \%$ to $30.4 \%$. Mean content of monoenoic fatty acids in the Pak- 
Paszczyk, B., Polak-Śliwińska, M., Łuczyńska, J. (2016). Fatty acids composition and trans isomers in cheeses and cheese-like products. Nauka Przyr. Technol., 10, 4, \#45. DOI: http://dx.doi.org/10.17306/J.NPT.2016.4.45

istani cheeses examined by Talpur et al. (2008) reached the level of $26.79 \%$. Similar content of fatty acids of the group in commercial cheeses was observed by Prandini et al. (2011). The content of monoenoic fatty acids in the fat isolated from ecological cheeses was from $18.71 \%$ to $32.37 \%$ (Paszczyk, 2015). The cheese-like products covered by the studies showed a significantly higher content of polyenoic fatty acids (Table 1), compared to commercial and farmer cheeses. Similar contents of polyenoic fatty acids, from $2.15 \%$ to $3.65 \%$, were reported by Grega et al. (2005) in commercial cheeses coming from the summertime period. The level of the acids in commercial cheeses from the winter period, examined by the authors, ranged from $1.67 \%$ to $2.82 \%$. Rutkowska et al. (2009) reported that polyenoic fatty acids, in cheeses from the period May-October, 2007, occurred in the range from $1.4 \%$ to $3.5 \%$ while in those from November, 2007 - August, 2008, the content was $1.4 \%$ to $2.5 \%$. Cheeses examined by Talpur et al. (2008) contained $3.25 \%$ of polyenoic fatty acids. Similar quantities of the acids in commercial cheeses were reported by Prandini et al. (2011). The content of polyenoic acids in ecological cheeses, examined in 2014 , oscillated in the interval from $1.70 \%$ to $3.72 \%$ (Paszczyk, 2015).

The presence, in the composition of fatty acids, of linoleic acid with conjugated bands (cis9trans $11 \mathrm{C} 18: 2, \mathrm{CLA})$ was reported in the fat isolated from all the commercial and farmer cheeses. According to the literature data, the isomer makes from $76.5 \%$ to $83 \%$ of all the CLA isomers both in milk and dairy products (Kee et al., 2010; Park, 2009). The model of animal feeding, connected with the season of the year, has a meaningful impact on CLA content in milk. The proportion of CLA in milk from the pasture feeding season is four-fold higher than that from the cowshed feeding (Lipiński et al., 2012; Żegarska et al., 2006). The level of cis 9 trans $11 \mathrm{C} 18: 2$ acid in dairy products may differ from the one in milk, being the raw material for their production (Lin, 2000; Murtaza et al., 2014). The results of some studies indicate that e.g. the industrial technological processing, the time of ripening, or the applied additions may promote an increase of CLA participation in fatty acids composition of some types of cheeses (Bzducha-Wróbel and Obiedziński, 2009; Kim et al., 2009; Lin, 2000; Murtaza et al., 2014). The carried out studies proved that the CLA contents in the examined commercial and farmer cheeses showed no meaningful differences (Table 2). Grega et al. (2005) reported that the CLA participation in commercial cheeses was placed in the interval from $0.20 \%$ to $0.95 \%$ in winter and from $0.61 \%$ to $1.57 \%$ in summer. According to Żegarska et al. (2008), the content of cis 9 trans $11 \mathrm{C} 18: 2$ acid in hard commercial cheeses, purchased in February and March, reached from $0.48 \%$ to $1.68 \%$ of fatty acids total composition. The hard cheeses bought in October and November showed the presence of CLA from $0.97 \%$ to $1.46 \%$. Conjugated linoleic acid was present at the level from $0.3 \%$ to $1.3 \%$ in cheeses from May-October, 2007 period as reported by Rutkowska et al. (2009). The authors also examined the cheeses from November, 2007 to August, 2008 and reported the presence of CLA from $0.2 \%$ to $0.6 \%$.

The cheeses examined in 2014 and coming from ecological production were characterized by a varied CLA content, from $0.20 \%$ to $1.21 \%$, in the total fatty acids composition (Paszczyk, 2015). The high variability of the acid content in the tested cheeses may be caused, on the one hand, by a varied milk quality, and, on the other, by varied production process conditions. Higher values of conjugated linoleic acid in some of the tested farmer cheeses may indicate that they were produced from summer milk and were 
Paszczyk, B., Polak-Śliwińska, M., Łuczyńska, J. (2016). Fatty acids composition and trans isomers in cheeses and cheese-like products. Nauka Przyr. Technol., 10, 4, \#45. DOI: http://dx.doi.org/10.17306/J.NPT.2016.4.45

Table 2. Content of trans isomers of C18:1 and C18:2 acids, as well as cis9trans 11 C18:2 (CLA) acid in total fatty acids of cheeses and cheese-like products (\%)

Tabela 2. Zawartość izomerów trans kwasów C18:1 i C18:2 oraz zawartość kwasu cis9trans11 C18:2 (CLA) w ogólnym składzie kwasów tłuszczowych serów i wyrobów seropodobnych (\%)

\begin{tabular}{|c|c|c|c|c|c|c|c|c|c|}
\hline \multirow[t]{2}{*}{$\begin{array}{l}\text { Acid } \\
\text { Kwas }\end{array}$} & \multicolumn{3}{|c|}{$\begin{array}{l}\text { Commercial cheeses } \\
\text { Sery handlowe } \\
(\mathrm{n}=8)\end{array}$} & \multicolumn{3}{|c|}{$\begin{array}{l}\text { Cheese-like products } \\
\text { Wyroby seropodobne } \\
\qquad(\mathrm{n}=8)\end{array}$} & \multicolumn{3}{|c|}{$\begin{array}{c}\text { Cheeses made by farmers } \\
\text { Sery farmerskie } \\
(\mathrm{n}=8)\end{array}$} \\
\hline & Min & Max & $\bar{x} \pm \mathrm{SD}$ & Min & Max & $\bar{x} \pm \mathrm{SD}$ & Min & Max & $\bar{x} \pm \mathrm{SD}$ \\
\hline$\sum$ trans $\mathrm{C} 18: 1$ & 2.15 & 3.85 & $\begin{array}{c}3.19^{\mathrm{a}} \\
\pm 0.59\end{array}$ & 0.05 & 3.08 & $\begin{aligned} & 1.28^{\mathrm{b}} \\
\pm & 1.23\end{aligned}$ & 1.75 & 4.04 & $\begin{array}{r}2.91^{\mathrm{b}} \\
\pm 0.90\end{array}$ \\
\hline$\sum$ trans $\mathrm{C} 18: 2$ & 0.49 & 0.87 & $\begin{array}{c}0.72^{\mathrm{a}} \\
\pm 0.02\end{array}$ & 0.27 & 0.50 & $\begin{array}{l}0.37^{\mathrm{b}} \\
\pm 0.08\end{array}$ & 0.46 & 0.85 & $\begin{array}{r}0.59^{\mathrm{a}} \\
\pm 0.15\end{array}$ \\
\hline $\begin{array}{l}\text { cis9trans } 11 \text { C18:2 } \\
\text { (CLA) }\end{array}$ & 0.45 & 1.02 & $\begin{aligned} & 0.77^{\mathrm{a}} \\
\pm & 0.18\end{aligned}$ & 0.00 & 0.09 & $\begin{aligned} & 0.02^{\mathrm{b}} \\
\pm & 0.03\end{aligned}$ & 0.36 & 1.21 & $\begin{array}{r}0.65^{\mathrm{a}} \\
\pm 0.29\end{array}$ \\
\hline
\end{tabular}

$\mathrm{n}$ - number of samples, Min - minimum value, Max - maximum value, $\bar{x}$ - mean value, $\mathrm{SD}$ - standard deviation.

Mean values denoted in the rows by the same letter do not differ statistically significantly $(\mathrm{p} \leq 0.05)$.

$\mathrm{n}$ - liczba próbek, Min - wartość minimalna, Max - wartość maksymalna, $\bar{x}$ - wartość średnia, SD - odchylenie standardowe.

Wartości średnie oznaczone w wierszach tą samą literą nie różnią się statystycznie istotnie $(\mathrm{p} \leq 0,05)$.

ripening for a longer time compared to the others from the group. CLA acid was found in the composition of not all of the examined cheese-like products. The presence of the conjugated linoleic acid was confirmed in four of the examined cheese-like products. The acid proportion in the total fatty acids composition of the products was very low, and reached from $0.02 \%$ to $0.09 \%$. The CLA mean content in cheese-like products was significantly lower compared to its mean value in the examined commercial and farmer cheeses (Table 2). Such a low content of conjugated linoleic acid in cheese-like products may indicate that the products contained an inconsiderable addition of milk fat in their composition. The cheese-like products purchased in Olsztyn in 2013 also showed low contents of milk fat (Paszczyk, 2014). Ritvanen et al. (2012) found no presence of CLA in the rape oil added cheeses they examined.

The contents of trans isomers of C18:1 acid separated from the commercial and farmer cheeses were at similar levels (Table 2). The total content of the isomers in the commercial cheeses purchased in February and March, and studied by Żegarska et al. (2006), was from $1.65 \%$ to $4.42 \%$ in the total fatty acids composition. The proportion of the isomers in cheeses coming from October and November ranged from $4.14 \%$ to $4.69 \%$. Isomers of trans C18:1 acid in ecological cheeses reached the value from $0.85 \%$ to $4.04 \%$ in the total fatty acids composition (Paszczyk, 2015). The proportion of trans C18:1 isomers in cheese-like products was meaningfully varied (Table 2). According to the study published in 2014, the content of trans C18:1 acid isomers in cheese-like products ranged from $0.05 \%$ to $3.18 \%$ (Paszczyk, 2014). The observed high variability of the content of trans $\mathrm{C} 18: 1$ acid isomers in cheese-like products may result from the fact that some manufacturers use esterified plant oils for the production of cheese-like products which, contrary to hydrogenated oils, contain very low amounts of trans iso- 
Paszczyk, B., Polak-Śliwińska, M., Łuczyńska, J. (2016). Fatty acids composition and trans isomers in cheeses and cheese-like products. Nauka Przyr. Technol., 10, 4, \#45. DOI: http://dx.doi.org/10.17306/J.NPT.2016.4.45

mers, or do not contain them at all. The studied commercial and farmer cheeses were characterized by close contents of trans C18:1 acid isomers. A meaningfully lower content of the isomers was found in cheese-like products (Table 2). The proportion of this group of isomers in hard cheeses purchased from February to March, and examined by Żegarska et al. (2008), ranged from $0.44 \%$ to $1.17 \%$, and in the cheeses bought from October to November from $0.96 \%$ to $1.11 \%$. The isomers proportion in the cheese-like products purchased in 2013 did not exceed 0.50\% (Paszczyk, 2014).

\section{Conclusions}

The tested commercial and farmer cheeses, as well as cheese-like products, showed varied content of fat and diverse composition of individual groups of fatty acids. Farmer cheeses were the group within which the highest differences in the content of fatty acids groups were observed. It can be concluded, on the basis of the research, that both commercial and farmer cheeses show a higher content of saturated and short-chain fatty acids, and a lower content of monoenoic and polyenoic acids compared to cheese-like products. Cheeses are a better source of conjugated linoleic acid in our diet than are cheese-like products.

\section{References}

Aljewicz, M., Cichosz, G., Kowalska, M. (2011). Produkty seropodobne, analogi serów topionych i dojrzewających. Żywn. Nauka Technol. Jakość, 78, 5, 16-25.

Aljewicz, M., Kowalska, M., Cichosz, G. (2010). Wartość odżywcza i biologiczna wyrobów seropodobnych i analogów serów. Przegl. Mlecz., 12, 4-10.

Aydin, R. (2005). Conjugated linoleic acid: chemical structure, sources and biological properties. Turk. J. Vet. Anim. Sci., 29, 2, 189-195.

Barłowska, J., Florek, M., Litwińczuk, Z. (2016a). Mleko i mięso zwierząt przeżuwających jako źródło substancji biologicznie czynnych. Część I. Mleko. Przegl. Hod., 2, 1-4.

Barłowska, J., Litwińczuk, Z. (2009). Genetyczne i środowiskowe uwarunkowania profilu kwasów tłuszczowych mleka. Med. Wet., 65, 5, 310-314.

Barłowska, J., Litwińczuk, Z., Domaradzki, P., Pastuszka, R., Wójcik-Saganek, A. (2016b). Wpływ sezonu na skład chemiczny i profil kwasów tłuszczowych mleka krowiego i koziego produkowanego w gospodarstwach ekologicznych. Żywn. Nauka Technol. Jakość, 104, 1, 45-56.

Bzducha-Wróbel, A., Obiedziński, M. (2009). Zmiany zawartości CLA w układach serów modelowych z dodatkiem Bifidobacterium animalis subsp. lactis i Lactobacillus acidophilus. Bromatol. Chem. Toksykol., 42, 3, 241-246.

Capuano, E., Gravink, R., Boerrigter-Eenling, R., van Ruth, S. M. (2015). Fatty acid and triglycerides profiling of retail organic, conventional and pasture milk: implications for health and authenticity. Int. Dairy J., 42, 58-63.

Cichosz, G. (2007). Prozdrowotne właściwości tłuszczu mlekowego. Przegl. Mlecz., 5, 4-8.

Ciołkowska, A., Kozioł, J., Gustaw, W. (2012). Sprzężony kwas linolowy (CLA) - bioaktywny składnik tłuszczu mlekowego. Przegl. Mlecz., 8, 10-15.

Folch, J., Lees, M., Sloane Stanley, G. H. (1957). A simple method for the isolation and purification of total lipides from animal tissues. J. Biol. Chem., 226, 497-509. 
Paszczyk, B., Polak-Śliwińska, M., Łuczyńska, J. (2016). Fatty acids composition and trans isomers in cheeses and cheese-like products. Nauka Przyr. Technol., 10, 4, \#45. DOI: http://dx.doi.org/10.17306/J.NPT.2016.4.45

Frelich, J., Šlachta, M., Hanuš, O., Špička, J., Samková, E., Węglarz, A., Zapletal, P. (2012). Seasonal variation in fatty acid composition of cow milk in relation to the feeding system. Anim. Sci. Pap. Rep., 30, 3, 219-229.

Grega, T., Sady, M., Najgebauer, D., Domagała, J., Pustkowiak, H., Faber, B. (2005). Seasonal changes in the level of conjugated linoleic acid (CLA) in ripened cheeses. Biotechnol. Anim. Husb., 21, 5-6-2, 251-253. DOI: 10.2298/BAH0502251G

ISO 15884:2002 (IDF 182:2002). (2002). Milk fat - Preparation of fatty acid methyl esters. Brussels: ISO.

Jensen, R. G. (2002). The composition of bovine milk lipids: January 1995 to December 2000. J. Dairy Sci., 85, 2, 295-350.

Kee, J.-I., Ganesan, P., Kwak, H.-S. (2010). Bioactive conjugated linoleic acid (CLA) in milk. Korean J. Food Sci. Anim. Resour., 30, 6, 879-885.

Kim, J. H., Kwon, O-J., Choi, N.-J., Oh, S. J., Jeong, H.-Y., Song, M.-K., Jeong, I., Kim, Y. J. (2009). Variations in conjugated linoleic acid (CLA) content of processed cheese by lactation time, feeding regimen, and ripening. J. Agric. Food Chem., 57, 8, 3235-3239. DOI: 10.1021/ jf8030.38u

Kuczyńska, B., Nałęcz-Tarwacka, T., Puppel, K., Gołębiewski, M., Grodzki, H., Slósarz, J. (2011). Zawartość bioaktywnych składników mleka w zależności od modelu żywienia krów w certyfikowanych gospodarstwach ekologicznych. J. Res. Appl. Agric. Eng., 56, 4, 7-13.

Lin, T. Y. (2000). Conjugated linoleic acid concentration as affected by lactic cultures and additives. Food Chem., 69, 1, 27-31.

Lipiński, K., Stasiewicz, M., Rafałowski, R., Kaliniewicz, J., Purwin, C. (2012). Wpływ sezonu produkcji mleka na profil kwasów tłuszczowych tłuszczu mlekowego. Żywn. Nauka Technol. Jakość, 80, 1, 72-80.

Murtaza, M. A., Huma, N., Hayat, Z., Murtaza, M. S., Meraj, A. (2014). Cheddar cheese from cow milk with elevated conjugated linoleic acid levels. J. Food Nutr. Res., 2, 8, 506-509. DOI: $10.12691 / \mathrm{jfnr}-2-8-12$

Park, Y. (2009). Conjugated linoleic acid (CLA): good or bad trans fat? J. Food Compos. Anal., 22 Suppl., S4-S12.

Parodi, P. W. (2003). Anti-cancer agent in milk fat. Aust. J. Dairy Technol., 58, 2, 114-118.

Paszczyk, B. (2014). Skład kwasów tłuszczowych i udział izomerów trans w wyrobach seropodobnych. Post. Tech. Przetw. Spoż., 1, 17-21.

Paszczyk, B. (2015). Skład kwasów tłuszczowych, udział CLA oraz izomerów trans C18:1 i C18:2 w serach z produkcji ekologicznej. Bromatol. Chem. Toksykol., 48, 4, 615-621.

PN-73/A-86232. (1973). Mleko i przetwory mleczne. Sery. Metody badań. Warszawa: PKN.

Popović-Vranjeś, A., Sović, M., Pejanović, R., Jovanović, S., Krajinović, G. (2011). The effect of organic milk production on certain milk quality parameters. Acta Vet. (Belgr.), 61, 4, 415421.

Prandini, A., Sigolo, S., Piva, G. (2011). A comparative study of fatty acid composition and CLA concentration in commercial cheeses. J. Food Compos. Anal., 24, 55-61.

Przybojewska, B., Rafalski, H. (2003a). Kwasy thuszczowe występujące w mleku a zdrowie człowieka (cz. 4). Kwas wakcenowy cis i trans. Przegl. Mlecz., 9, 343-346.

Przybojewska, B., Rafalski, H. (2003b). Kwasy thuszczowe występujące w mleku a zdrowie człowieka. Sprzężony kwas linolowy CLA (cz. 2). Przegl. Mlecz., 5, 173-175.

Przybojewska, B., Rafalski, H. (2004). Kwasy thuszczowe występujące w mleku a zdrowie człowieka (cz. 5). Skład izomerów pozycyjnych i geometrycznych nienasyconych kwasów tłuszczowych występujących w thuszczu mlekowym. Przegl. Mlecz., 1, 30-34.

Radkowska, I. (2013). Wpływ systemu utrzymania i żywienia na zawartość kwasów thuszczowych, witamin oraz makroelementów w mleku krów rasy holsztyńsko-fryzyjskiej. Rocz. Nauk. Zootech., 40, 2, 171-182. 
Paszczyk, B., Polak-Śliwińska, M., Łuczyńska, J. (2016). Fatty acids composition and trans isomers in cheeses and cheese-like products. Nauka Przyr. Technol., 10, 4, \#45. DOI: http://dx.doi.org/10.17306/J.NPT.2016.4.45

Rembiałkowska, E., Załęcka, A. (2012). Mleko ekologiczne a konwencjonalne - różnice w wartości odżywczej. Przegl. Mlecz., 11, 8-9.

Ritvanen, T., Putkonen, T., Peltonen, K. (2012). A comparative study of the fatty acid composition of dairy products and margarines with reduced or substituted fat content. Food Nutr. Sci., 3, 9, 1189-1196. DOI: 10.4236/fns.2012.39156

Rutkowska, J., Sadowska, A., Tabaszewska, M., Stołyhwo, A. (2009). Skład kwasów thuszczowych serów podpuszczkowych pochodzących z rejonu Polski: północnego, wschodniego i centralnego. Bromatol. Chem. Toksykol., 42, 3, 263-269.

Sobotka, W., Stanek, M., Fiedorowicz, E. (2015). Prozdrowotne właściwości tłuszczu mlekowego w zależności od rasy krów. Probl. Hig. Epidemiol., 96, 4, 808-811.

Talpur, F. N., Bhanger, M. I., Memon, N. N. (2008). Fatty acid composition with emphasis on conjugated linoleic acid (CLA) and cholesterol content of Pakistani dairy products. Pol. J. Food Nutr. Sci., 58, 3, 313-320.

Zeppa, G., Giordano, M., Gerbi, V., Arlorio, M. (2003). Fatty acid composition of Piedmont "Ossolano" cheese. Lait, 82, 167-173.

Żebrowska, A., Banczar, G., Molik, E. (2009). Właściwości prozdrowotne tłuszczu mlekowego. Wiad. Zootech., 47, 2, 19-23.

Żegarska, Z. (2005). Składniki tłuszczu mlekowego o potencjalnym działaniu przeciwnowotworowym. Przegl. Mlecz., 6, 4-6.

Żegarska, Z., Paszczyk, B., Borejszo, Z. (2008). Conjugated linoleic acid (CLA) and trans C18:1 and C18:2 isomers in fat of some commercial dairy products. Pol. J. Nat. Sci., 23, 1, 248-256.

Żegarska, Z., Paszczyk, B, Rafałowski, R., Borejszo, Z. (2006). Annual changes in the content of unsaturated fatty acids with 18 carbon atoms, including cis9trans11 C18:2 (CLA) acid, in milk fat. Pol. J. Food Nutr. Sci., 15/56, 4, 409-414.

Żelazna, K., Popielarska, A. (2003). Mleko i produkty mleczarskie w żywieniu człowieka. Przem. Spoż., 10, 26-31.

\title{
SKŁAD KWASÓW TŁUSZCZOWYCH ORAZ IZOMERÓW TRANS W SERACH ORAZ WYROBACH SEROPODOBNYCH
}

\begin{abstract}
Streszczenie
Wstęp. Sery stanowią bardzo ważny składnik naszej diety. Asortyment serów na polskim rynku jest bardzo duży. Obok serów handlowych i farmerskich pochodzących z indywidualnych gospodarstw można zakupić wyroby seropodobne, które z uwagi na niższą cenę są często nabywane przez konsumentów. Celem badań była ocena składu kwasów tłuszczowych, ze szczególnym uwzględnieniem zawartości kwasów cis9trans11 C18:2, (CLA) oraz izomerów trans kwasu C18:1 i C18:2 w serach handlowych, serach farmerskich oraz wyrobach seropodobnych.

Material i metody. Ocenie poddano handlowe sery podpuszczkowe dojrzewające pochodzące od różnych producentów ( 8 produktów), wyroby seropodobne pochodzące od różnych producentów ( 8 produktów) oraz farmerskie sery podpuszczkowe dojrzewające pochodzące od indywidualnych producentów (8 produktów). Oznaczenia składu kwasów thuszczowych dokonano metodą GC-FID w 100-metrowej kolumnie kapilarnej z fazą CP Sil 88. Do identyfikacji kwasów thuszczowych wykorzystano referencyjny thuszcz mlekowy oraz wzorce estrów metylowych kwasów thuszczowych firm Sigma i Supelco.

Wyniki. Badania wykazały, że sery handlowe i sery farmerskie oraz wyroby seropodobne charakteryzowały się zróżnicowaną zawartością tłuszczu, a także zróżnicowanym składem poszczegól-
\end{abstract}


Paszczyk, B., Polak-Śliwińska, M., Łuczyńska, J. (2016). Fatty acids composition and trans isomers in cheeses and cheese-like products. Nauka Przyr. Technol., 10, 4, \#45. DOI: http://dx.doi.org/10.17306/J.NPT.2016.4.45

nych grup kwasów tłuszczowych. W obrębie jednej grupy produktów największe różnice w zawartości poszczególnych grup kwasów tłuszczowych zaobserwowano w serach farmerskich.

Wnioski. Na podstawie wykonanych badań można stwierdzić, że sery zarówno handlowe, jak i farmerskie charakteryzują się większą niż wyroby seropodobne zawartością kwasów nasyconych i krótkołańcuchowych oraz mniejszą niż wyroby seropodobne zawartością kwasów monoenowych i polienowych. Sery są lepszym źródłem sprzężonego kwasu linolowego w naszej diecie niż wyroby seropodobne.

Słowa kluczowe: kwasy thuszczowe, kwas CLA, izomery trans, sery, wyroby seropodobne

Corresponding address - Adres do korespondencji:

Beata Paszczyk, Katedra Towaroznawstwa i Badań Żywności, Uniwersytet Warmińsko-Mazurski w Olsztynie, pl. Cieszyński 1, 10-719 Olsztyn,Poland, e-mail: paszczyk@uwm.edu.pl

Accepted for publication - Zaakceptowano do opublikowania:

26.10.2016

For citation - Do cytowania:

Paszczyk, B., Polak-Śliwińska, M., Luczyńska, J. (2016). Fatty acids composition and trans isomers in cheeses and cheese-like products. Nauka Przyr. Technol., 10, 4, \#45. DOI: http://dx.doi. org/10.17306/J.NPT.2016.4.45 